\title{
MOLECULAR CHARACTERIZATION OF CLOSTRIDIUM PERFRINGENS ISOLATED FROM TURKEYS
}

\author{
ELGAOS, M.I. ${ }^{\text {; }}$ KHALIL, M.R. ${ }^{1}$; MAHMOUD, A. ABDELRAHMAN ${ }^{2}$ AND AHMED, H. RAMADAN ${ }^{2}$ \\ ${ }^{1}$ Department of Poultry Diseases, Animal Health Research Institute, Mansoura Branch, Egypt. \\ ${ }^{2}$ Department of Microbiology, Animal Health Research Institute, Mansoura Branch, Egypt.
}

Received: 31 December 2019; Accepted: 31 January 2020

\begin{abstract}
A total of 82 C. perfringens isolates (41\%) were recovered from 200 samples collected from 100 turkeys (20 apparently healthy, 40 clinically diseased and 40 freshly dead), 4-6 weeks old. The clinical signs of diseased birds were sudden mortality, depression, ruffled feathers, diarrhea, dehydration, emaciation and decrease in feed consumption with increase in water consumption. While, postmortem findings were consistent with necrotic enteritis (NE), the small intestine was severely affected. Small and demarcated lesions were found in the duodenal loop, hepatitis and cholecystitis were also observed. Unopened intestines were gas-filled and enlarged with thin wall. The intestinal contents were dark due to necrotic material. The opened intestines showed necrotic lesions of varying severity of the mucosa. Isolation and biochemical identification of C.perfringens were done. Five C.Perfringens field isolates were analyzed by PCR assay to determine the presence of some toxin genes. In all tested isolates, the Cpa gene (alpha toxin) was detected (100\%) confirming the isolates were C.perfringens. While, $C p b$ (beta toxin) gene was detected in two samples (40\%). But the Etx gene (epsilon toxin) was not detected in any isolate (0\%). $\mathrm{NetB}$ gene was detected in two isolates (40\%). Antimicrobial susceptibility of 40 C.perfringens field isolates recovered from turkeys revealed that C.perfringens isolates were sensitive to Ampicillin (85\%), Amoxicillin (85\%), Penicillin (82.5\%), Florfenicol (72.5\%), Enrofloxacin (67.5\%), Vancomycin (65\%), Bacitracin (60\%), Oxytetracyclin (32.5\%), Lincomycin (22.5\%) and Clindamycin $(15 \%)$.These five $C$. perfringens isolates were also screened by PCR which detected the presence of tetracycline resistance gene $\operatorname{tet}(\mathrm{K})$ in three isolates $(60 \%)$ and Lincomycin resistance gene $\operatorname{lin}(\mathrm{B})$ in three isolates $(60 \%)$.
\end{abstract}

Key words: C. perfringens, multiplex PCR, toxin and resistance genes.

\section{INTRODUCTION}

Clostridium perfringens is an important bacterial pathogen, especially in poultry, where it can lead to both subclinical and clinical disease. Necrotic enteritis is caused by toxins produced by $C$. perfringens, which is often found in the intestinal tract of healthy birds, and when it grows in the intestinal tract, it can produce toxins. The disease may occur in the form of outbreaks in poultry and especially in broiler and turkeys flocks, causing acute clinical disease characterized by necrotic enteritis (Engstrom et al., 2003).

Clostridium perfringens is a Gram-positive, sporeforming and anaerobic bacterium responsible for a wide range of diseases in humans and animals (Manteca et al., 2002). The pathogenicity of $C$. perfringens is closely related to the production of major lethal toxins (alpha, beta, epsilon, and iota

Corresponding author: Dr. ELGAOS, M.I.

E-mail address: elgaos122@gmail.com

Present address: Department of Poultry Diseases, Animal Health Research Institute, Mansoura Branch, Egypt toxins) and other toxins, including enterotoxin (Hatheway, C. L., 1990). Clostridium perfringens is commonly classified to toxigenotypes based on the types of toxins they produce. The main toxins produced by strains of $C$. perfringens are alpha, beta, epsilon, and iota toxins (Songer and Meer, 1996).Necrotic enteritis is caused predominantly by C. perfringens type $\mathrm{A}$, and to a lesser extent by type C (Cooper and Songer, 2009). Alpha-toxin has long been believed to be the critical virulence factor in NE (Al-Sheikhly and Truscott, 1977), but Cooper et al. (2010) showed that alpha toxin may not be an essential causative factor of NE. More recently, a novel toxin, NE toxin B (NetB), has been discovered and strongly associated with the pathogenesis of $\mathrm{NE}$ (Keyburn et al., 2010). Some authors consider NetB the most important bacterial virulence factor for development of NE, although both $N e t B$-positive and $N e t B$-negative strains have been found associated with NE (Timbermont et al., 2011).

The conventional method of C.perfringens typing is based on the detection and typing of the toxins with toxin neutralization test in mice. This procedure consumes a lot of antisera and experimental animals. 
Moreover, it is time consuming. In recent years, molecular techniques such as polymerase chain reaction (PCR) are increasingly used to type $C$. perfringens (Baums et al., 2004). The Present study aimed to determine the prevalence of necrotic enteritis in turkeys, detect some toxin genes and antimicrobial resistance genes in C.perfringens isolated from turkeys (field isolates) using PCR assay and study antimicrobial susceptibility to choice the effective antibiotics against C.perfringens.

\section{MATERIALS AND METHODS}

\section{Samples:}

A total of 200 samples (100 liver and 100 intestine) were collected from 100 turkeys, 4-6weeks age (20 apparently healthy, 40 clinically diseased and 40 freshly dead) were obtained from different turkey farms in Dakahlia province. The samples were collected aseptically in sterile separate labeled bags in an ice box then were transferred without delay to be examined bacteriologically for isolation and identification of the causative microbe.

Clinical and Postmortem examination:

All turkeys were examined clinically, then sacrificed and immersed in a disinfectant before being autopsied. Gross pathological changes were recorded, summarized and presented with results for both freshly dead and clinically diseased turkeys.

\section{Isolation and identification:}

The samples were inoculated into tubes of freshly prepared boiled then rapidly cooled cooked meat medium (CMM) (Oxoid) and incubated anaerobically for 24 hours at $37^{\circ} \mathrm{C}$ in a Gaspak anaerobic jar (Willis, A.T. ,1977). A loopful of inoculated fluid medium was streaked onto neomycin sulphate $(200 \mathrm{ug} / \mathrm{ml})$ sheep blood agar plates then re-incubated anaerobically for $24 \mathrm{~h}$ at $37^{\circ} \mathrm{C}$ (Cruickshank et al., 1975). The lecithinase activity of suspected $C$. perfringens colonies were tested on egg yolk agar medium. Typical colonies (lecithinase producer and showed double zone of hemolysis on blood agar medium) were picked up, sub-cultured and purified for further biochemical identification tests (Koneman et al., 1983).

Molecular characterization of $C$. perfringens by PCR:

Five C.perfringens isolates (field isolates) were subjected to PCR test in PCR unit, Animal Health Research Institute (AHRI), Egypt.

DNA extraction from $C$. perfringens isolates:

Extraction was done by using Patho Gene-Spin TM, DNA/RNA Extraction kit iNtRON cat. No. 17154 Korea according to the instructions of the manufacturer.

\section{Oligonucleotide Primer:}

The PCR primers used in this study are listed in table (1).

Oligonucleotide primer used in PCR reactions were synthesized by Sigma Company, (Germany). PCR reaction was performed in Gradient Thermal cycler ( $S$ 1000 Thermal cycler Bio-RAD USA). The reaction mixture (total volume of $50 \mu \mathrm{l}$ ) was $25 \mu \mathrm{l} \mathrm{M}$. Mix (Cosmo PCR red Master Mix (2X) Willowfort W1020300x), England), $2 \mu$ l target DNA, $1 \mu$ l of each primers (containing $10 \mathrm{p} \mathrm{mole} / \mu \mathrm{l}$ ) and the mixture was completed by water nuclease free to 50 $\mu 1$.

\section{Analysis of the PCR Products:}

Run $5-8 \mu \mathrm{l}$ of the PCR product in parallel with a 100bp ladder molecular weight marker (100bp DNA Ladder: Thermo Scientific Gene Ruler, Cat. No. SM0243 or SM0321 USA) on a $1.5 \%$ agarose gel (Agarose, Sigma, USA) in TBE (Tris Boric EDTA) $1 \mathrm{X}$ buffer. Run for $90 \mathrm{~min}$ at about $110 \mathrm{~V}$ on a mini horizontal electrophoresis unit (BIO-RAD, USA). The gel was stained in ethidium bromide for 2030min. The gel was visualized under UV transilluminator (Spectroylyne Model TR-312 A) under UV light and photographed by Canon digital camera.

Table 1: Target genes, PCR Primers and Length of amplification products of $C$. perfringens.

\begin{tabular}{|c|c|c|c|}
\hline Target gene & Primer sequence $\left(5^{\prime}-3^{\prime}\right)$ & Reference & $\begin{array}{l}\text { Length of amplification } \\
\text { products }(\mathrm{bp})\end{array}$ \\
\hline Cpa & $\begin{array}{l}\text { F: GCTAATGTTACTGCCGTTGA } \\
\text { R: CCTCTGATACATCGTGTAAG }\end{array}$ & \multirow[b]{3}{*}{$\begin{array}{c}\text { Ahsani } \\
\text { et al., } 2010\end{array}$} & 324 \\
\hline$C p b$ & $\begin{array}{l}\text { F:GCGAATATGCTGAATCATCTA } \\
\text { R:GCAGGAACATTAGTATATCTTC }\end{array}$ & & 196 \\
\hline Etx & $\begin{array}{l}\text { F: GCGGTGATATCCATCTATTC } \\
\text { R: CCACTTACTTGTCCTACTAAC }\end{array}$ & & 655 \\
\hline$N e t B$ & $\begin{array}{l}\text { F:GCTGGTGCTGGAATAAATGC } \\
\text { R:TCGCCATTGAGTAGTTTCCC }\end{array}$ & $\begin{array}{c}\text { Anthony et al., } \\
2010\end{array}$ & 383 \\
\hline $\operatorname{Lin}(\mathrm{B})$ & $\begin{array}{l}\text { F: CCTACCTATTGTTTGTGGAA } \\
\text { R: ATAACGTTACTCTCCTATTC }\end{array}$ & $\begin{array}{c}\text { Bozdogan et al., } \\
1999\end{array}$ & 906 \\
\hline $\operatorname{Tet}(\mathrm{K})$ & $\begin{array}{l}\text { F: TTATGGTGGTTGTAGCTAGAAA } \\
\text { R: AAAGGGTTAGAAACTCTTGAAA }\end{array}$ & $\begin{array}{l}\text { Masco et al., } \\
2006\end{array}$ & 382 \\
\hline
\end{tabular}


Table 2: PCR cycling conditions for target genes.

\begin{tabular}{|c|c|c|c|c|}
\hline Target gene & Stage & Temp. $\left({ }^{\circ} \mathrm{C}\right)$ & Time & No. of cycles \\
\hline \multirow{4}{*}{$\begin{array}{l}\text { Cpa } \\
\text { Cpb } \\
\text { Etx }\end{array}$} & Initial denaturation & 94 & $2 \mathrm{~min}$ & 1 \\
\hline & Denaturation & 94 & $15 \mathrm{sec}$. & \multirow{3}{*}{35} \\
\hline & Annealing & 55 & $30 \mathrm{sec}$. & \\
\hline & extension & 68 & $1 \mathrm{~min}$. & \\
\hline \multirow{3}{*}{ NetB } & Denaturation & 94 & $30 \mathrm{sec}$ & \multirow{3}{*}{30} \\
\hline & Annealing & 55 & $30 \mathrm{sec}$ & \\
\hline & extension & 72 & $1 \mathrm{~min}$. & \\
\hline \multirow{5}{*}{$\operatorname{Lin}(\mathrm{B})$ and $\operatorname{Tet}(\mathrm{K})$} & Initial denaturation & 94 & $5 \mathrm{~min}$ & 1 \\
\hline & Denaturation & 94 & $45 \mathrm{sec}$ & \multirow{3}{*}{35} \\
\hline & Annealing & 54 & $45 \mathrm{sec}$ & \\
\hline & extension & 72 & $1 \mathrm{~min}$ & \\
\hline & Final extension & 72 & $5 \mathrm{~min}$ & 1 \\
\hline
\end{tabular}

In vitro Antibiotic Susceptibility Test:

Fourty (40) C.perfringens isolates (field isolates) were subjected to antibiotic sensitivity test against 10 commonly used antibiotics in poultry farms. The antimicrobial susceptibility profile Ampicillin,
Amoxicillin, Penicillin, Florfenicol, Enrofloxacin, Vancomycin, Bacitracin, Oxytetracyclin, Lincomycin and Clindamycin was tested by disk diffusion methods according to Clinical and Laboratory Standards Institute (CLSI, 2012).

\section{RESULTS}

Table 3: Prevalence of $C$. perfringens in examined samples collected from turkeys.

\begin{tabular}{|c|c|c|c|c|}
\hline Samples & No. of ex & amples & $\begin{array}{c}\text { No. of positive } \\
\text { samples }\end{array}$ & $\%$ \\
\hline \multirow{2}{*}{ Apparently healthy birds (20) } & Intestine & 20 & 3 & $15 \%$ \\
\hline & Liver & 20 & 0 & $0 \%$ \\
\hline \multirow{2}{*}{ Clinically diseased birds (40) } & Intestine & 40 & 24 & $60 \%$ \\
\hline & Liver & 40 & 14 & $35 \%$ \\
\hline \multirow{2}{*}{ Freshly dead birds (40) } & Intestine & 40 & 26 & $65 \%$ \\
\hline & Liver & 40 & 15 & $37.5 \%$ \\
\hline Total & \multicolumn{2}{|c|}{200} & 82 & $41 \%$ \\
\hline
\end{tabular}

Table 4: Results of multiplex PCR and PCR assay for detection of some $C$. perfringens toxin and antimicrobial resistance genes.

\begin{tabular}{|c|c|c|c|c|c|c|}
\hline \multirow{4}{*}{ Isolate } & \multicolumn{6}{|c|}{ Results } \\
\hline & \multicolumn{4}{|c|}{ Toxin genes } & \multicolumn{2}{|c|}{ Antimicrobial resistance genes } \\
\hline & Cpa & $C p b$ & Etx & NetB & $\operatorname{Tet}(\mathrm{K})$ & $\operatorname{Lin}(\mathrm{B})$ \\
\hline & $\begin{array}{c}\text { Alpha } \\
\text { toxin gene }\end{array}$ & $\begin{array}{l}\text { Beta toxin } \\
\text { gene }\end{array}$ & $\begin{array}{l}\text { Epsilon } \\
\text { toxin gene }\end{array}$ & $\begin{array}{l}\text { NE toxin } \\
\text { B gene }\end{array}$ & $\begin{array}{c}\text { Tetracycline } \\
\text { resistance gene K }\end{array}$ & $\begin{array}{c}\text { Lincomycin resistance } \\
\text { gene B }\end{array}$ \\
\hline 1 & + & + & - & - & + & - \\
\hline 2 & + & - & - & + & + & + \\
\hline 3 & + & + & - & + & - & + \\
\hline 4 & + & - & - & - & - & + \\
\hline 5 & + & - & - & - & + & - \\
\hline Total & $100 \%$ & $40 \%$ & $0 \%$ & $40 \%$ & $60 \%$ & $60 \%$ \\
\hline
\end{tabular}




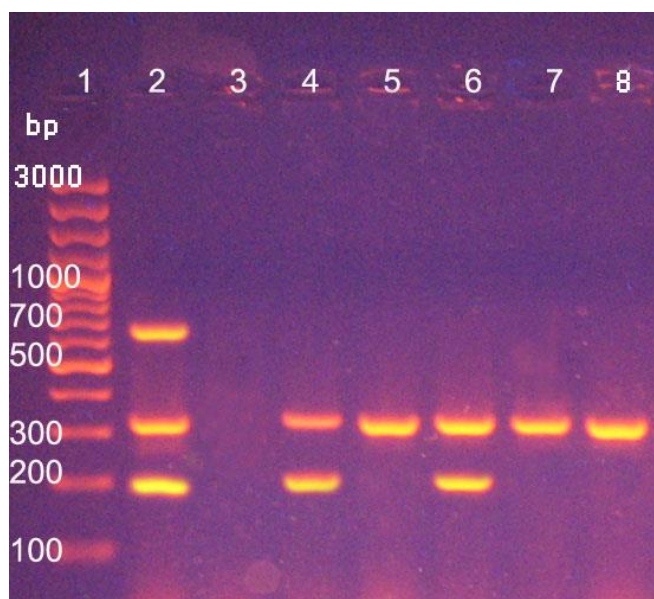

Fig. 1: Agarose gel (1.5\%) electrophoresis of multiplex PCR products obtained with various $C$. perfringens toxin genes (Cpa gene (324bp), Cpb gene (196bp) and Etx gene (655bp).

Lane 1: DNA marker (GeneRuler 100 bp DNA Ladder)

Lane 2: Control Positive (mix of various toxin types).

Lane 3: Control Negative

Lane 4-8: PCR products of toxin genes from $C$. perfringens field isolates.

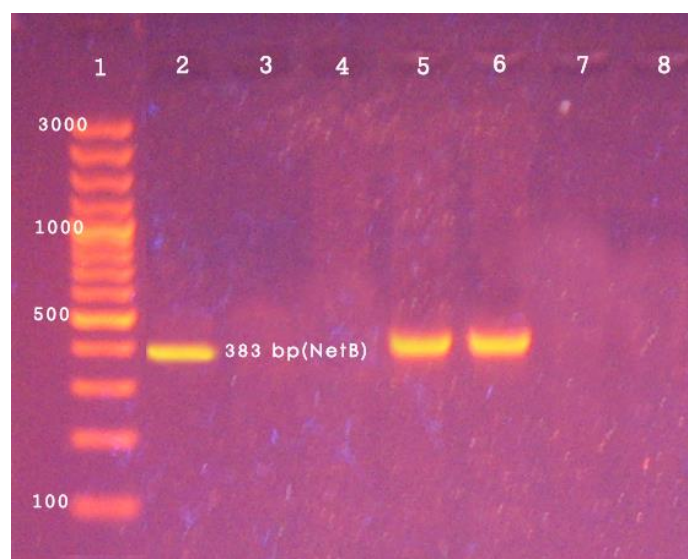

Fig. 2: Agarose gel (1.5\%) electrophoresis of PCR products showing amplification of 383 bp fragment using $N e t B$ gene primer.

Lane 1: DNA marker (Gene Ruler 100 bp DNA Ladder)

Lane 2: Control Positive.

Lane 3: Control Negative

Lane 4-8: PCR products of NetB gene from $C$. perfringens field isolates.

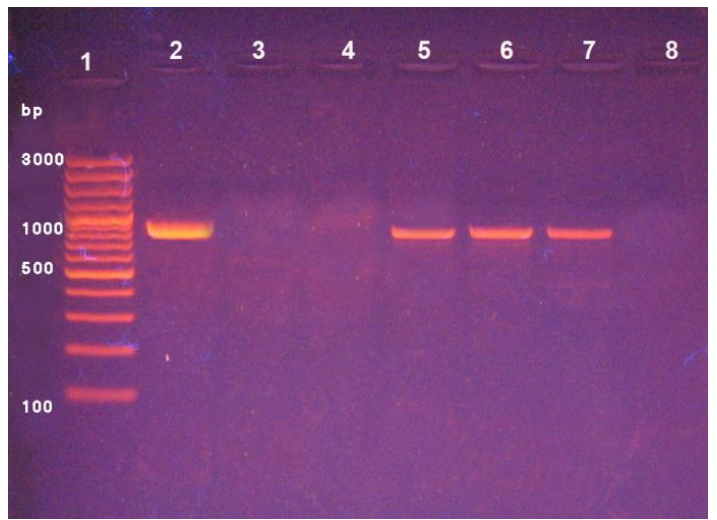

Fig. 3: Agarose gel (1.5\%) electrophoresis of PCR products showing amplification of 906 bp fragment using LinB gene primer.

Lane 1: DNA marker (Gene Ruler 100 bp DNA Ladder)

Lane 2: Control Positive.

Lane 3: Control Negative

Lane 4-8: PCR products of $\operatorname{Lin}(\mathrm{B})$ gene from $C$. perfringens field isolates. 


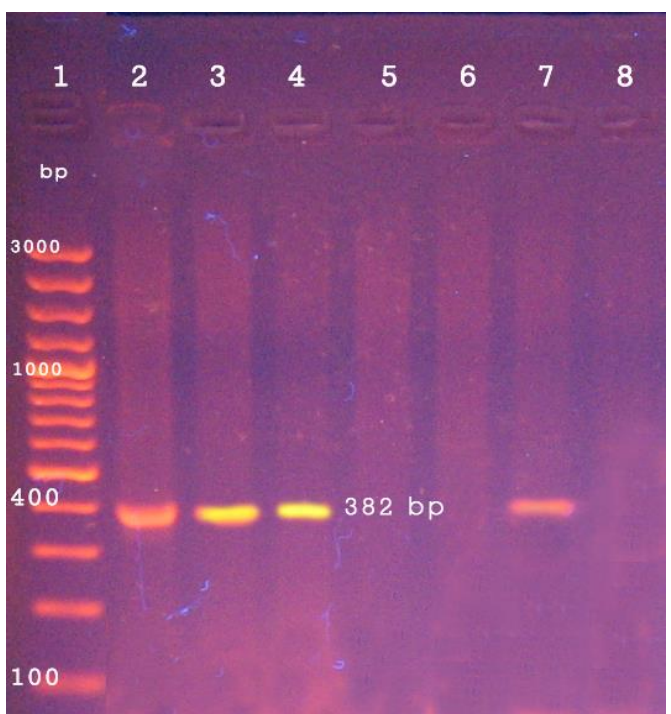

Fig. 4: Agarose gel (1.5\%) electrophoresis of PCR products showing amplification of 382 bp fragment using $\operatorname{Tet}(\mathrm{K})$ gene primer.

Lane 1: DNA marker (Gene Ruler 100 bp DNA Ladder)

Lane 2: Control Positive.

Lane 8: Control Negative

Lane 3-7: PCR products of Tet $(\mathrm{K})$ gene from $C$. perfringens field isolates.

Table 5: Antibiotic sensitivity and resistance pattern for (40) C. perfringens field isolates.

\begin{tabular}{cccccc}
\hline \multirow{2}{*}{ Antibiotic } & $\begin{array}{c}\text { No. of tested } \\
\text { isolates }\end{array}$ & No. & $\%$ & No. & Resistant \\
\cline { 3 - 6 } & 40 & 34 & 85 & 6 & 15 \\
\hline Ampicillin & 40 & 34 & 85 & 6 & 15 \\
\hline Amoxicillin & 40 & 33 & 82.5 & 7 & 17.5 \\
\hline Penicillin & 40 & 29 & 72.5 & 11 & 27.5 \\
\hline Florfenicol & 40 & 27 & 67.5 & 13 & 32.5 \\
\hline Enrofloxacin & 40 & 26 & 65 & 14 & 40 \\
\hline Vancomycin & 40 & 24 & 60 & 16 & 67.5 \\
\hline Bacitracin & 40 & 13 & 32.5 & 27 & 77.5 \\
\hline Oxytetracyclin & 40 & 9 & 22.5 & 31 & 85 \\
\hline Lincomycin & 40 & 6 & 15 & 34 & \\
\hline Clindamycin & 40 & & & &
\end{tabular}

\section{DISCUSSION}

Necrotic enteritis in turkeys has emerged in Egypt in the last years as an economic problem causing great losses and great concern for the breeders. The present study was undertaken to study the incidence of the disease, antimicrobial susceptibility and detection of some toxin and antimicrobial resistance genes of $C$. perfringens field isolates involved in apparently healthy and diseased turkeys.

In the present investigation, turkeys from affected flocks with C.perfringens showed clinical signs including a sudden increase in mortality observed in the flock, depression, ruffled feathers, diarrhea, dehydration and emaciation with decrease in feed consumption and sometimes an increase in water consumption. These findings agreed with that observed by Saif et al. (2003). While, postmortem findings were consistent with necrotic enteritis (NE) with the small intestines which most frequently and severely affected. Small and demarcated lesions were found in the duodenal loop, hepatitis and choleocystitis were also observed. Unopened intestines were gas-filled and enlarged and their wall appeared thin. The intestinal contents were dark due to necrotic material. The opened intestines showed necrotic lesions of varying severity of the mucosa. In severe cases, the mucosa was covered with a typically thick greenish or yellowish diphtheric pseudomembrane ("Turkish towel"). These findings agreed with that observed by Lyhs et al. (2013).

In general, the investigation of 200 samples collected from apparently healthy, clinically diseased and freshly dead turkeys revealed that, only 82 samples were positive to $C$. perfringens the prevalence rate was $41 \%$ (Table 3 ). Nearly similar results were recorded by Heidy et al. (2015) who recorded that the prevalence rate of $C$. perfringens in turkeys was 45.9\%. On the other hand, Gad et al. (2011) and Parvaiz et al. (2017) recorded that the prevalence 
rates were $29.1 \%$ and $31.01 \%$, respectively. These differences may be due to age, immune status of birds, nutrition and management.

PCR technology is considered to be a convenient and highly reliable tool for molecular detection of the major toxin genes such as (alpha, beta, epsilon, and iota toxin genes) (Yoo et al., 1997).

In the present study, five $C$. Perfringens isolates (field isolates) were analyzed by multiplex PCR in order to detect the presence of some toxin genes. A mixture of primers of Cpa (alpha toxin) gene (324bp), $C p b$ (beta toxin) gene (196bp) and etx (epsilon toxin) gene (655bp) were used. Also, these Five $C$. Perfringens isolates were analyzed by PCR in order to detect the NetB (necrotic enteritis toxin B) gene (383 bp).

All toxigenic types of C.perfringens are able to produce alpha toxin which has lecithinase activity and causes tissue necrosis especially in small intestine so alpha toxin is mainly responsible for necrotic enteritis in birds Keyburn et al. (2010).

Our results revealed that the CPa gene (alpha toxin) was detected in all tested isolates (100\%) confirming the isolates as $C$. perfringens (Table 4 and Figure 1). This was in the same direction with the result of Engstrom et al. (2003) and Lyhs et al. (2013) who detected Cpa gene (alpha toxin) in all tested isolates of $C$. perfringens.

Enterotoxins are frequently cytotoxic and kill cells by altering the apical membrane permeability of the mucosal cell of the intestinal wall. They are mostly pore-forming toxins, secreted by bacteria that led to form pores in cell membrane causing cell necrosis (Cooper and Songer, 2009).

With respect to $C p b$ gene (beta toxin), it was detected in two of the tested isolates $(40 \%)$ (Table 4 and Figure 1) indicating that $C p b$ has a role in development of necrotic enteritis. This was agreed with that recorded by Ahsani et al. (2010).

The Etx gene (epsilon toxin) was not detected in any of the tested isolates (0\%) (Table 4 and Figure 1). These results agreed with that reported by Baums et al. 2004.

NetB gene (necrotic enteritis toxin B) is located on a plasmid and encodes a pore-forming toxin, which perforates the plasma membrane and thereby damages host cells (Keyburn et al., 2010).

In the present investigation, $N e t B$ gene was detected in two of the isolates $(40 \%)$ that were recovered from turkeys with necrotic enteritis (Table 4 and Figure 2). These results were nearly similar with that recorded by Abildgaard et al. (2010) who reported that $52 \%$ of the $C$. perfringens strains isolated from NE-affected birds were netB-positive. On the other hand, Keyburn et al. (2010) reported that $70 \%$ of the $C$. perfringens strains isolated from NE-affected birds were netBpositive and Lyhs et al. (2013) reported that only $8 \%$ of $C$. perfringens isolates recovered from turkeys with NE were $n e t B$-positive.

Antimicrobial susceptibility of 40 C.perfringens isolates recovered from turkeys showed high sensitivity to penicillin group (Ampicillin, Amoxicillin and Penicillin, 85\%, 85\% and 82.5\%, respectively). This was in the same direction with the findings of Mona and Abdelhafez, (2017). While, $C$. perfringens isolates showed high resistance to Clindamycin, Lincomycin and Oxytetracyclin (85\%, $77.5 \%$ and $67.5 \%$, respectively). These results run parallel with that recorded by Martel et al. (2004).

C. perfringens isolates were also screened by PCR assay for the detection of some antibiotic resistance genes, Tetracycline resistance gene, $\operatorname{tet}(\mathrm{K})(382 \mathrm{bp})$ and Lincomycin resistance gene, $\operatorname{lin}(\mathrm{B})(906 \mathrm{bp})$. In three of the tested isolates $(60 \%)$, the tet $(\mathrm{K})$ and $\operatorname{lin}(\mathrm{B})$ genes were detected (Table 4 and Figures 3 and 4). These findings support the antimicrobial susceptibility test results. These results were in agreement with Ahmadreza et al. (2009) who detected $\operatorname{tet}(\mathrm{K})$ and $\operatorname{lin}(\mathrm{B})$ genes in C.perfringens isolates.

\section{CONCLUSION}

The presence of some toxin genes confirmed the pathogenic potential of the isolated $C$. perfringens strains and their association with clinical manifestations and postmortem findings. Antibiotic sensitivity and resistance pattern showed high antibiotic resistance of $C$. perfringens isolates which require strict regulations on the use of antibiotics in veterinary therapy to minimize the emergence of resistant bacteria in turkeys which may increase the public health problem.

\section{REFERENCES}

Abildgaard, L.; Sondergaard, T.E.; Engberg, R.M.; Schramm, A. and Højberg, O. (2010): In vitro production of necrotic enteritis toxin $\mathrm{B}, \mathrm{NetB}$, by netB-positive and netB-negative Clostridium perfringens originating from healthy and diseased broiler chickens. Vet. Microbiol. 144:231-235.

Ahmadreza Gholamiandehkordi; Venessa Eeckhaut; Anouk Lanckriet; Leen Timbermont; Lotte Bjerrum; Richard Ducatelle; Freddy Haesebrouck and Filip Van Immerseel (2009): Antimicrobial resistance in Clostridium perfringens isolates from poultry in Belgium. Vet Res Commun (2009) 33:1031-1037. 
Ahsani, M.R.; Mohammadabadi, M.R. and Shamsaddini, M.B. (2010): Clostridium perfringens isolate typing by multiplex PCR. The Journal of Venomous Animals and Toxins including Tropical Diseases 16(4): 573-578.

Al-Sheikhly, F. and Truscott, R.B. (1977): The interaction of Clostridium perfringens and its toxins in the production of necrotic enteritis of chickens. Avian Dis. 21: 256 - 263.

Anthony, L.K; Xu-Xia, Y.; Trudi, L.B.; Filip, V.I.A.; Julian, I.R and Robert, J.M. (2010): Association between avian necrotic enteritis And Clostridium perfringens strains expressing NetB toxin.

Baums, C.G.; Schotte, U.; Amtsberg, G. and Goethe, $R$. (2004): Diagnostic multiplex PCR for toxin genotyping of Clostridium perfringens isolates. Veterinary Microbiology, 20, 11-16.

Bozdogan, B.; Berrezouga, L.; Kuo, M.; Yurek, D.A.; Farley, K.A.; Stockman, B.J. and Leclercq, R. (1999): A new resistance gene, linB, conferring resistance to lincosamides by nucleotidylation in Enterococcus faecium HM1025. Antimicrob. Agents Chemother. 43, 925-929.

CLSI (2012): The Clinical and Laboratory Standards Institute: Methods for dilution antimicrobial susceptibility tests for bacteria that grow aerobically; approved standard. $9^{\text {th }}$ Edition. M07-A9, 32(2).

Cooper K.K. and Songer J.G. (2009): Necrotic enteritis in birds: A paradigm of enteric infection by Clostridium perfringens type A. Anaerobe 15:55-60.

Cooper, K.K.; Theoret, J.R.; Stewart, B.A.; Trinh, H.T.; Glock, R.D. and Songer, J.G. (2010): Virulence for chickens of Clostridium perfringens isolated from poultry and other sources. Anaerobe 16: 289 - 292.

Cruickshank, R.; Duguid, J.P.; Marmion, B.R. and Swain, R.H.A. (1975): Medical Microbiology, 12th Ed., Living stone, London, New York, 812-825.

Engstrom, B.E.; Fermer, C.; Lindberg, A.; Saarinen, E.; Baverud, V. and Gunnarsson, A. (2003): Molecular typing of isolates of Clostridium perfringens from healthy and diseased poultry. Vet. Microbiol. 94:225-235.

Gad, W.; Hauck, R.; Kruger, M. and Hafez, H.M. (2011): Prevalence of Clostridium Perfringens in commercial turkeys and layer flocks. Arch. Geflugelk., 75(2).S. 74-79.

Hatheway, C.L. (1990): Toxigenic clostridia. Clin. Microbiol. Rev.3: 66-98.).

Heidy Abo Elyazeed; AmanyElsayed; Sherif Marouf and Mohamed Refai (2015): Typing of Clostridium Perfringens isolates recovered from Necrotic Enteritis in Turkeys in Egypt by Multiplex PCR. International Journal of Research Studies in Biosciences (IJRSB) Volume 3, Issue 8, August 2015, PP 1-6.
Keyburn, A.L.; Yan, X.-X.; Bannam, T. L.; Van Immerseel, F.; Rood, J.I. and Moore, R.J. (2010): Association between avian necrotic enteritis and Clostridium perfringens strains expressing NetB toxin.Vet. Res. 41: 21- 28.

Koneman, E.W.; Allen, S.D.; Dowell, V.R. and Summers, H.W. (1983): Color atlas and text book of diagnostic microbiology. 2nd Ed. J. B. LippinCott, New York, London.

Lyhs, U.; Perko-Mäkelä, P.; Kallio, H.; Brockmann, A.; Heinikainen, S.; Tuuri, H. and Pedersen, K. (2013): Characterization of Clostridium perfringens isolates from healthy turkeys and from turkeys with necrotic enteritis. Poultry Science 92: 1750-1757.

Manteca, C.; Daube, G; Jauniaux, T.; Linden, A.; Pirson, V.; Detilleux, J.; Ginter, A.; Coppe, P.; Kaeckenbeeck, A. and Mainil, J.G. (2002): A role for the Clostridium perfringens $\beta-2$ toxin in bovine enterotoxaemia. Vet. Microbiol.86: 191-202.

Martel, A.; Devriese, L.A.; Cauwerts, K.; De Gussem, K.; Decostere, A. and Haesebrouck, F. (2004): Susceptibility of Clostridium perfringens strains from broiler chickens to antibiotics and anticoccidials. Avian Pathol. 33, 3-7.

Masco, L.; Van Hoorde, K.; De Brandt, E.; Swings, J. and Huys, G. (2006): Antimicrobial susceptibility of Bifidobacterium strains from humans, animals and probiotic products. J. Antimicrob. Chemother. 58, 85-94.

Mona, A.A. Abdel Rahman and Abdelhafez, S. Abdelhafez (2017): Prevalence of Clostridium perfringens isolated from poultry. AHRI, $1^{\text {st }}$ inter. con. Abstracts book, Pp. 36.

Parvaiz, S. Dar; Shakil, A. Wani; Aasim, H. Wani; Hussain, I.; Rafia Maqbool; Muhammad, Y. Ganaie; Zahid, A. Kashoo and Qureshi, S. (2017): Isolation, identification and molecular characterization of Clostridium perfringens from poultry in Kashmir valley, India. Journal of Entomology and Zoology Studies, 5(5): 409-414

Saif, Y.M.; Barnes, H.J.; Glisson, J.R.; Fadly, A.M.; McDougald, L.R. and Swayne, D.E. (2003): Diseases of Poultry (11 thed.). Iowa State University Press., Blackwell Publishing Company, London, United Kingdom Pp. 849.

Songer, J.G. and R.R. Meer (1996): Genotyping of Clostridium perfringens by polymerase chain reaction is a useful adjunct to diagnosis of clostridial enteric disease in animals. Anaerobe. , (2): 197-203.

Timbermont, L.; Haesebrouck, F.; Ducatelle, R. and Van Immerseel, F. (2011): Necrotic enteritis in broilers: An updated review on the pathogenesis. Avian Pathol.40: 341- 347.

Willis, A. T. (1977): Anaerobic Bacteriology-Clinical and Laboratory Practice. $3^{\text {rd }}$ ed. 
Yoo, H.S.; Lee, S.U.; Park, K.Y. and Park, Y.H. (1997): Molecular typing and epidemiological survey of prevalence of Clostridium perfringens types by multiplex PCR. J Clin. Microbiol. 1997; 35(1): 228-32.

\section{التوصيف الجزيئي للكلستريديم برفرنجنز المعزوله من دجاج الرومي \\ محد ابراهيم الجاعوص ، مصطفي ريبع خليل ، محمود عبل/لنعيم عب الرحمن ، أحمد حجازي رمضان}

E-mail: elgaos122@gmail.com Assuit University web-site: www.aun.edu.eg

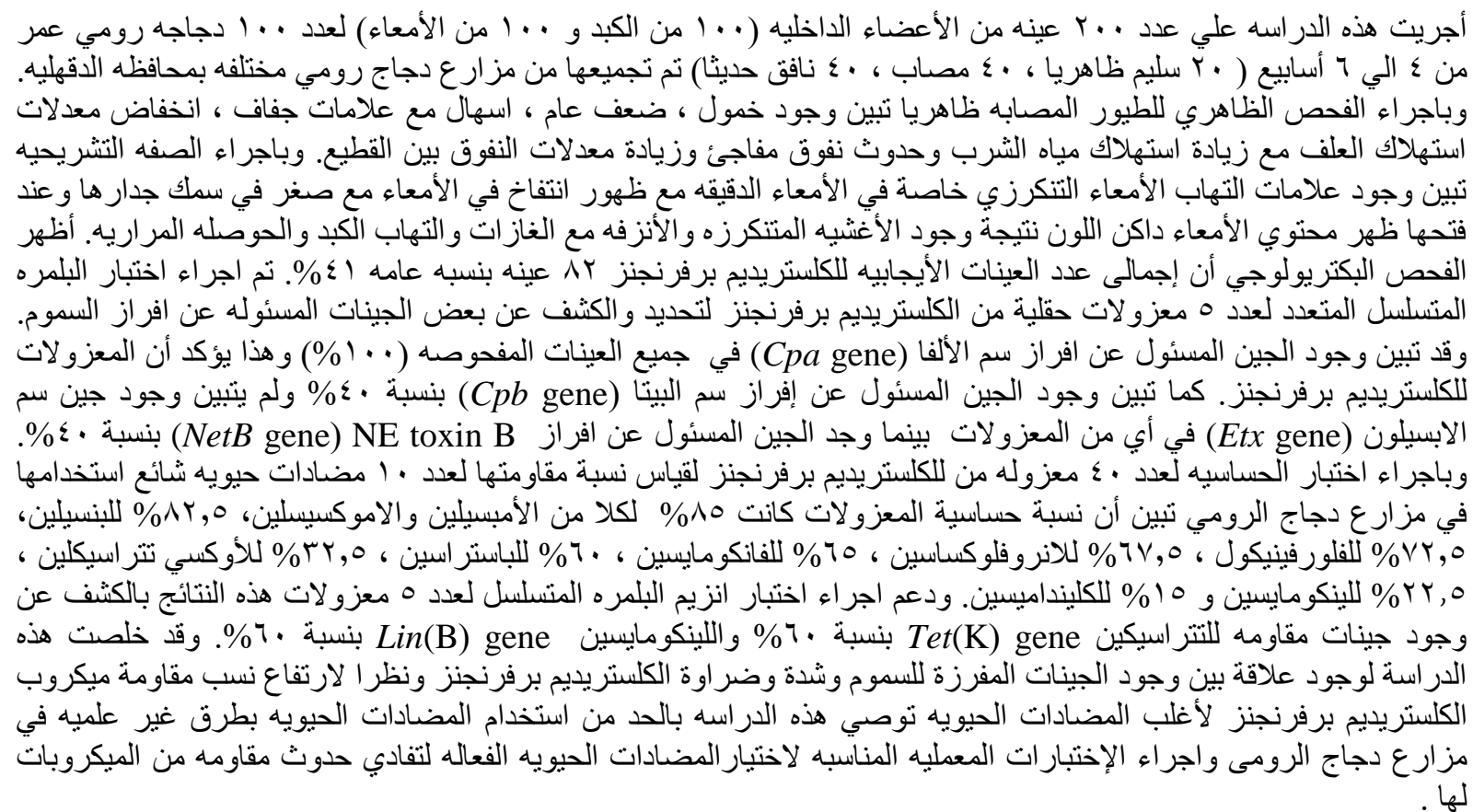

